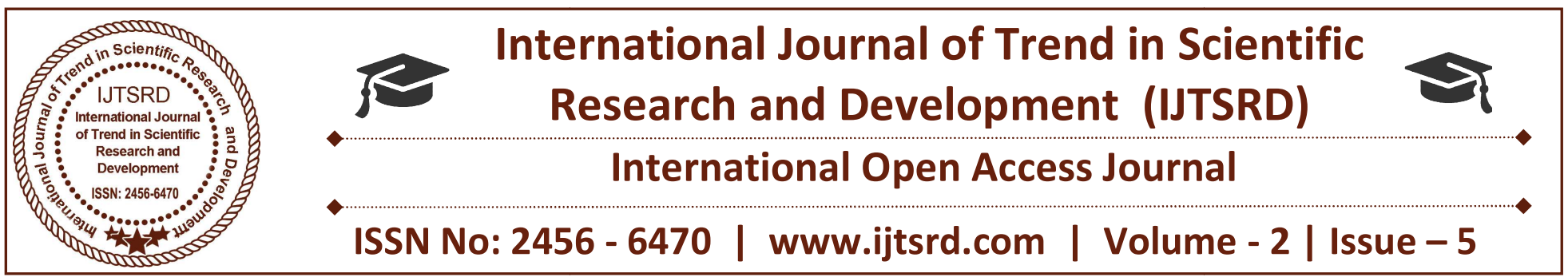

\title{
Commercial Utility of Bailment
}

\author{
Kartik Mandloi \\ B.B.A., LL.B. (Hon), Indore Institute of Law \\ Indore, Madhya Pradesh, India
}

\section{ABSTRACT}

The researcher has done the research on the Commercial utility of Bailment. Bailment means Transfer of personal property by one party (the bailor) in the possession, but not ownership, of another party (the bailee) for a particular purpose. Such transfer is made under an express or implied contract (called bailment contract or contract of bailment) that the property will be redelivered to the bailor on completion of that purpose, provided the bailee has no lien on the goods (such as for non-payment of its charges). The bailee is under an obligation to take reasonable care of the property placed under its possession. Bailment contracts are a common occurrence in everyday life: giving clothes to a launderer, leaving car with an auto mechanic, handing over cash or other valuable to a bank, etc.

The research contains the brief introduction of commercial use of bailment, purpose of bailment, types of bailment, common forms of commercial bailment, elements, rights and responsibilities of bailee and bailor, termination of bailment following up with Real life cases of Responsibility under bailment, various examples and a commercial sector that is Bailment contract of a transaction of FedEx Company.

\section{INTRODUCTION}

The term bailment refers to the transfer of personal property to another person for safekeeping, or for the other person to control or use temporarily. A bailment is a form of contractual relationship, even if no contract has been signed. The person receiving the property (the "bailee") has possession and control over the property for a specific period of time, during which he or she is responsible to take reasonable care of the property. The original owner of the property

(the "bailor") retains ownership interest during this time.

A Contract where one party delivers goods to the other upon return basis to fulfil a specific purpose is called bailment contract. It includes two parties namely; bailer and bailee. The person who is delivering the goods is called bailer and the person to whom goods are delivered, is called bailee.

Example: A has handed over his fan to B for the purpose of repairs. It is bailment contract. A is bailer and $\mathrm{B}$ is bailee. Similarly $\mathrm{X}$ has handed over his dress $\mathrm{Y}$ for the purpose of washing. It is also bailment Contract where $\mathrm{X}$ is bailer and $\mathrm{Y}$ is bailee.

Bailment is different from a contract for sale of the property, even where such contracts include sellerfinancing, or the making of payments for the property. This is because the intent of a contract of sale is to transfer ownership of the property to the buyer. In a bailment, ownership of the property does not transfer, and transfer is never an intended consequence.

In order for a bailment to exist, the bailee must have both the intent to possess the property, and actual possession the property. The bailor intends that the property will be returned to him at the end of a specified period of time, or after the purpose for which the property was given has been completed.

\section{DEFINITION OF BAILMENT}

Transfer of personal property by one party (the bailor) in the possession, but not ownership, of another party (the bailee) for a particular purpose. Such transfer is made under an express or implied contract (called bailment contract or contract of bailment) that the 
property will be redelivered to the bailor on completion of that purpose, provided the bailee has no lien on the goods (such as for non-payment of its charges). The bailee is under an obligation to take reasonable care of the property placed under its possession. Bailment contracts are a common occurrence in everyday life: giving clothes to a launderer, leaving car with an auto mechanic, handing over cash or other valuable to a bank, etc. A "bailment" is the delivery of goods by one person to another for some purpose, upon a contract that they shall, when the purpose is accomplished, be returned or otherwise disposed of according to the directions of the person delivering them.

The person delivering the goods is called the "bailor". The person to whom they are delivered is called the "bailee".

\section{EXPLANATION:-}

If a person already in possession of the goods of another contract to hold them as a bailee, he thereby becomes the bailee, and the owner becomes the bailor of such goods, although they may not have been delivered by way of bailment.

\section{PURPOSES OF BAILMENT}

Because a bailment is often created without an actual written contract, there are many situations in which the law recognizes a bailment exists. These include bailments created:

For the mutual benefit of both the bailor and bailee- created when there is to be an exchange of services or performances between the parties, such as when the bailor leaves his property with the bailee to be repaired, after which the bailor will be paying for the repairs.

For the sole benefit of the bailor - created when the owner of a valuable item, such as a TV, a car, or a piece of jewelry, leaves the item with someone for safekeeping, with no expectation of compensation being made to the friend or other party.

For the sole benefit of the bailee- created when the owner of an item loans the property to another person, with no expectation of receiving payment or compensation, but expecting that the item will be returned to the owner.

\section{TYPES OF BAILMENT}

\section{Gratuitous Bailment}

A bailment with no considerations is called a gratuitous bailment. In this kind of bailment neither the bailor, nor the bailee is entitled to any remuneration or reward. Such a bailment may be for the exclusive benefit of either party, i.e., the bailor or the bailee, discussed as below.

\section{Bailment for the exclusive benefit of the bailor}

In this case the bailor delivers the goods for the exclusive benefits and the bailee does not derive any benefit out of it. For example, "A" leaves his pets with "B", his neighbour to be looked after during A's physical absence. In this case, $A$ alone is being benefited by the bailment. Or, if you park your car in your neighbour's premises to be taken care in your absence, you as a bailor derive the exclusive benefit from the bailment.

\section{Bailment for the exclusive benefit of the bailee}

This is the case where a bailor delivers the goods to the bailee for the exclusive benefits of the bailee and does not gain anything from the contract himself. For example; you lend your book to a friend of yours for a week without any charge or favour. In this case the recipient of the book as a bailee, is the sole beneficiary of this transaction of bailment.

\section{Non-Gratuitous Bailment}

Contrary to gratuitous bailment, a non-gratuitous bailment or bailment for reward is one that involve some consideration passing between the bailor and the bailee. Obviously in this case the delivery of goods takes place for the mutual benefit of both the parties.

For example, "A" hires "B's" car. Here B is the bailor and receives the hire charges and $A$ is the bailee and enjoys the use of the car. Similarly, when you give your PC or laptop for repair to some techie, both you and the computer techie are going to be benefited by this contract - while you get your computer repaired, he gets his fees or charges.

\section{COMMON FORMS OF COMMERCIAL}

\section{BAILMENT}

A. Ware houses; storage bailments. Many commercial bailments arise out of the storage of goods.

1. Nomenclature. Persons who provide storage services for a fee are in the warehouse business and are called warehouses or warehousemen. The 
person who stores goods in a warehouse is called a bailor. The person providing the storage service who receives the goods into a warehouse is called a bailee.

2. Examples of warehouses. Examples of warehouses that are common in the United States include: elevators for the storage of grains; cotton gins that store ginned cotton; tobacco warehouses that store tobacco; cold storage sheds that store perishable fruits and vegetables; warehouses for the storage of business inventory of every kind and description; natural underground basins for the storage of natural gas or petroleum products; terminal warehouses at seaports for the storage of goods that will be loaded onto ships for international and domestic trade; tank farms for the storage of petroleum products prior to shipment to a refinery.

3. Documents used. The documents used in storage bailments include warehouse receipts, scale tickets, weight slips. Any other document that the warehouse business recognizes as equivalent to a warehouse receipt is also an acceptable bailment document regardless of the specific name used for the document.

B. Trucks, trains, planes, ships, pipelines: transportation bailments.

Many commercial bailments arise out of the transportation of goods. While trucks, trains, planes and ships are easily recalled as transporters, one should not forget that in the modern world pipelines are also very important transporters.

\section{Nomenclature.}

Persons who provide transportation services for a fee are in the transportation business and are called "carriers". Carriers are equivalent to warehouse bailees. The person who delivers goods to a carrier for shipment is called the "shipper" or the "consignor". The shipper or consignor is equivalent to warehouse bailors. The person to whom the carrier ordinarily should deliver the goods is called the consignee.

\section{Documents used.}

The documents used in transportation bailments include bills of lading, dock receipts, marine bills of lading, air waybills, and train waybills. Any other document that the transportation business recognizes as equivalent to a bill of lading is also an acceptable bailment document regardless of the specific name used for the document.
Business organization for warehouses and carriers Warehouses an carriers (the bailee in a bailment relationship) can be legally organized as an individual business, or a partnership, or a corporation, or a cooperative, or any other legal entity recognized by law. Most commercial warehouses are either corporations or agricultural cooperatives. Most commercial carriers are corporations. For common forms of business organization see Kozyris" Business Organizations", this work.

\section{ELEMENTS OF A BAILMENT}

Many civil lawsuits arise over the failure of a bailee to protect the property of the bailor. In order to prove that a bailment existed, and therefore that the bailee had a duty to reasonably protect the property, three elements must be proven. These include:

Delivery- The property must be delivered to the actual care and/or control of the bailee. Control of the property does not necessarily require actual physical possession in some cases, but by giving a means of access to the property, such as providing keys to a storage unit where the property is kept, the bailor engages in constructive delivery of the property.

Acceptance- A bailee must knowingly accept possession and/or control of the property. This means that no one can unwittingly become a bailee, as, because a bailment is a type of contract, knowledge and acceptance of the bailment terms are essential elements.

Consideration- Unlike a typical contract, in which both parties must receive something of value, only one party need receive something of value in a bailment. When a bailment is created for the sole benefit of the bailee, such as when one party loans the use of his car to another, just to be a good friend, a bailment is created, even though the bailor receives nothing of value.

\section{RIGHTS AND RESPONSIBILITIES OF BAILEE}

In the event a written bailment contract is made, the rights and duties of both parties should be spelled out. In many cases, no written contract exists, though the law recognizes that a bailee must exercise a duty of care in protecting the property. This is the purpose of the tiered system of liability, with specific duties varying according to the type of bailment. 
Bailment for Mutual Benefit - a bailee's failure to take reasonable care of the property may result in the bailee's liability for any damages that might be incurred due to his negligence.

Bailment for Sole Benefit of Bailor - a bailee has a lesser duty of care, being responsible only for damages that result due to his gross negligence, or act of bad faith.

Bailment for Sole Benefit of Bailee - a bailee has a duty of taking extraordinary care for the property, and may only use the property for the purpose agreed upon when the bailment is created. The bailee is responsible for all damages to the property that arise from his failure to properly take care of it.

\section{TERMINATION OF BAILMENT}

Termination of a bailment occurs when its intended purpose has been achieved, or when the parties agree that it is ended. If a bailment is created for an undefined period of time, it may be terminated at will by either party by providing the other party with due notice of the intent to terminate. Following completion of the purpose for the bailment, the bailee has a responsibility to return the property to its owner. In some cases, if return of the property is impossible, due to no fault of the bailee, the bailee is not held liable for non-delivery. This might occur if the property was destroyed in a fire that was not the bailee's fault, or if the property blew away in a tornado. In all other situations, failing to return the property as scheduled or agreed, the bailee may be liable for the tort of conversion.

\section{Real Life Cases of Responsibility Under Bailment}

The issue of responsibility or liability for damage to, or loss of, property under bailment is a common subject of civil lawsuits across the U.S. In each of these cases, the judge must determine whether the three required elements of a bailment existed at the time of loss or damage occurred, as well as the value of the property lost, in order to make a judgment.

\section{Hotel Loses Guest's Valuable Jewelry}

At Hotel in Minnesota, a guest left a valuable ring with the desk clerk, with instructions for the ring to be delivered to a jeweler. The desk clerk lost the ring, so it was never delivered to the jeweler, and he never reported to either his employer, or the guest, that it had been lost.
The guest sued the hotel as the bailee of the ring, as she had delivered possession of the ring to the hotel's employee for the purpose of having it delivered to the jeweler. The guest proved to the trial court's satisfaction that, as a bailee, the hotel was liable for the jewelry, and awarded damages in the amount of over $\$ 2,000$.

The hotel appealed the decision to the Minnesota Supreme Court, arguing that, in order for a bailment to exist, there must be a mutual agreement between the parties. Since the hotel had never consented to become a bailee, it cannot be held responsible. The hotel also argued that, because it did not know the value of the ring in question, it was not a bailee. The hotel further argued that it received no consideration or benefit for taking care of the ring.

The Minnesota Supreme Court affirmed the trial court's decision saying:

1. The hotel's desk clerk consented to a bailment on behalf of his employer.

2. The hotel's desk clerk new that he had accepted control of a valuable ring

3. The hotel took possession of the ring as part of its regular business services, and so generated good will and return guests as a result of those services

\section{Examples of Bailment:}

A lends a car to B for his driving only without charge. A sells a horse to B who leaves the horse in the possession of $\mathrm{A}$

\section{Bailment Is Concerned Only With Goods:}

Goods, as defined in sec. 2(7) of the Sale Goods Act, 1930 , mean every kind of movable property other than money and actionable claims.

Agreement: There must be an agreement between the bailor and the bailee. This agreement may be either express or implied. However, a bailment may be implied by law also. For Example, bailment between a finder of goods and owner of goods

Delivery of goods: There must be delivery of goods. It means that the possession of goods must be transferred. Delivery may be actual or constructive.

Purpose: The delivery of goods must be for some intended purpose.

Return of Specific Goods: The goods which form the subject matter of a bailment must be returned to the 
bailor or the bailor or otherwise dispose off according to the directions of the bailor, after the accomplishment of purpose or after the expiry of period of the bailment. It may be noted that the same goods must be returned in their original form or desired form. Thus, goods must be returned in specie though they may undergo a change of form.

\section{RIGHTS OF BAILOR AND BAILEE}

Enforcement of rights.

Avoidance of contract.

Return of goods lent gratuitously.

Compensation from a wrong-doer.

Delivery of goods to one of several joint bailors of goods.

Delivery of goods to bailor without title.

Right to apply to court to stop delivery.

Right of action against trespassers.

\section{BAILMENT CONTRACT OF A TRANSACTION} OF A FEDEX COMPANY

\section{Introduction:}

FedEx Corporation was founded as FDX Corporation in January 1998 with the acquisition of Caliber System Inc. by Federal Express. With the purchase of Caliber, FedEx started offering other services besides express shipping. Caliber subsidiaries included RPS, a small-package ground service; Roberts Express, an expedited shipping provider; Viking Freight, a regional, less-than-truckload freight carrier serving the Western United States; Caribbean Transportation Services, a provider of airfreight forwarding between the United States and the Caribbean; and Caliber Logistics and Caliber Technology, providers of logistics and technology solutions. FDX Corporation was founded to oversee all of the operations of those companies and its original air division, Federal Express.

In January 2000, FDX Corporation changed its name to FedEx Corporation and rebranded all of its subsidiaries. Federal Express became FedEx Express, RPS became FedEx Ground, Roberts Express became FedEx Custom Critical, and Caliber Logistics and Caliber Technology were combined to make up FedEx Global Logistics. A new subsidiary called FedEx Corporate Services was formed to centralize the sales, marketing, customer service for all of the subsidiaries. In February 2000, FedEx acquired Tower Group International, an international logistics company. FedEx also acquired World Tariff, a customs duty and tax Information Company, Tower
Group and World Tariff were rebranded to form FedEx Trade Networks.

Relating FedEx with the Provisions Available in Indian Sales of Goods Act.

Bailment means only transfer of possession from the bailor to the bailee. This may be for any one of the objects, namely, safe custody, use, carriage from one place to another, etc. Similarly, FedEx Express is the bailor and the person for whom courier is made is bailee. The provision available in Indian Sale of Act is as follows:

$>$ How Contract of sale is made

$>$ Two parties to contract

$>$ Contract of Sale includes agreement to sale

$>$ Transfer of property

$>$ Possession and property

$>$ Goods

$>$ Price

$>$ Conditions and Warranties

$>$ Acceptance of goods by buyer

$>$ Auction sale

Measure for compensation and damages

\section{How Contract Is Made By FedEx?}

Contract between FedEx and bailee is made by another party who has offered FedEx to deliver courier for the bailee. In this that party who has got the possession of good, agreed to transfer its possession to another person through the help of FedEx. Delivery of the goods might be immediate or after certain period of time. A contract by conduct of the parties is only valid in case of FedEx.

\section{Two Parties to Contract:}

There are always two parties in BAILMENT CONTRACT. First person who gives and second person who receives. Only in case of joint owners there might exceed the number of parties. In case of FedEx, FedEx will be one party and courier receiver will be a second party. They had a relation of bailor and bailee among them.

\section{Transfer of Property:}

"Property" means the general property in goods, and not merely a special property. Property doesn't mean money. If goods are given for hire, lease, hire purchase or pledge, 'general property' is not transferred and hence it is not a 'sale'. FedEx will transfer the property from sender to the receiver. 
During the period of transfer of property FedEx is liable for the any act which may damage the good.

\section{Possession and Property:}

Possession and property is two different thing. When FedEx get the goods to be delivered possession of good will be changed to the FedEx but not the property or the ownership is changed.

\section{Goods}

Every kind of movable property comes under the contract of sale. FedEx also delivers all kind of movable properties, except some special properties like stock and shares, growing crops, grass, and things attached to or forming part of the land.

\section{Price}

Consideration for the delivery of the good is money. FedEx charges money according to the weight of the courier. Contract is not complete without the consideration so, sales of good act have declared money as a consideration for the work that FedEx does.

\section{Conditions And Warranties}

Condition and warranties is the another provision provided by the sales of good act. According to this if FedEx made any mistake and caused courier to be damaged it is the responsibility of the FedEx to pay for that. If the courier is damaged than it may lead to breach of contract until the compensation is paid.

\section{Acceptance of Goods By Buyer}

The duty of FedEx is only completed when the receiver of the courier accepts or receives the courier; the Sale of Good act also supports this view. Contract of Sale is completed not by mere delivery of goods but by acceptance of goods by buyer. 'Acceptance' does not mean mere receipt of goods. It means checking the goods to ascertain whether they are as per contract. Where goods are delivered to the buyer which he has not previously examined, he is not deemed to have accepted them unless and until he has had a reasonable opportunity of examining them for the purpose of ascertaining whether they are in conformity with the contract.

\section{Auction Sale}

According to the sale of good act if the delivery was not successful because of without any fault of FedEx than FedEx have to try to return that good to it owner but owner is unknown or good is going to be damage than FedEx is legible to sale it through auction after making public announcement.

\section{Measure for Compensation and Damages}

According to the sale of good act there is no any special provision for measuring the compensation of the damages. Being a commercial company FedEx will provide compensation after examining the loss bared by the buyer/seller.

\section{CONCLUSION}

Indian sales of good act which mean a contract whereby the seller transfers or agrees to transfer the property in goods to the buyer for a price. There may be a contract of sale between one part-owner and another. [Section 4(1)]. A contract of sale may be absolute or conditional. [Section 4(2)]. Are provision of contract which should be fallowed while dealing with bailment contract. Bailment is the process of making delivery of an asset or other type of property. Generally, this type of transaction involves the owner of the assets choosing to temporarily place them in the control of another individual. The person who delivers the asset is usually known as the bailor, while the recipient of the assets is known as the bailee. It helps to know basic requirement during the process of bailment contract. It helps both bailor and bailee to solve problems which may arise during the course of fulfilment contract.

FedEx is a courier company which deals with bailor and bailee. All the provisions including duties of bailor and baileehas been related with provisions provided by the Sale of Good Act, 1930. The conclusion is some of the provision provided by Sale of Good Act are not followed by the FedEx company and it has also made it few additional provisions to attract customers. 